\title{
Japan's Defence: Today and Tomorrow
}

HISAO IWASHIMA

\section{Introduction}

When the Pacific War was over, I was taking a training to become a commanding officer of the KORYU (Seadragon), a five-man midget submarine, modified version of the two-man submarine which penetrated Pearl Harbor in 1941. Missions in these submarines were not suicidal, but very nearly so, because they were automatically forced to the surface after firing one torpedo out of two due to the loss of balance. They would float in front of the target for about twenty seconds, submerge to normal depth, fire the second torpedo and come up again. It was a "secret weapon" in the hands of the Japanese Imperial Navy before the end of the war. About 150 such submarines were ready to fight against the landing forces of the United States.

I mention this to underline the difference between my feelings at that time, and my feelings now. I had no fear of death during the war. I was not afraid of fighting against a superior force for the sake of the nation. But I am much more afraid of death now. Although I have taught for a long time at the National Defence College (currently the National Institute for Defence Studies) about international security, my sentiments are very different from what they were in the prewar period.

The difference in my feelings is also tied to the atomic bombing of Hiroshima. I was in the Submarine School at Otake, 40 kilometers away from Hiroshima when the bomb was dropped, and saw the flash of the explosion and the mushroom cloud, and felt the shockwave. Two days later, I walked through Hiroshima for about two hours. I was told that if I had been there for five hours I would have been fatally affected, but fortunately I was not exposed to the radiation long enough for that. When I came back to Kure, which was near my home port at that time, my group and I got very drunk, to try and expunge the nightmare we had seen. The drinking helped save my life, flushing out the radiation. I do not know: whether to believe that or not, but in any case I am still here.

Only someone who had gone through the same experience, I think, could understand the anxieties I had after the war, especially when I was about to 
have my first child. Even my wife did not really understand. At any rate, these feelings make up a part of my mentality. Frankly speaking, the Japanese "nuclear allergy" is something that ought to persist. It is unacceptable to use atomic weapons for any reason, under any reason, under any conditions. At the same time, I have to acknowledge the effectiveness of nuclear weapons as a deterrent. This is the dilemma I have to confront in my own thinking.

\section{A Retrospect of the Japanese \\ Postwar National Security Policies}

Looking back at the'Japanese national security posture in the postwar period, it is very interesting to find various forms of "shock" or "surprise" that shaped the national stance at that moment. The first shock was the atomic bombs, dropped at Hiroshima and Nagasaki. This "atom shock" accelerated the Japanese unconditional surrender and caused the Japanese decision to start as a new peaceful nation with no arms. The "New Constitution" was thus wholeheartedly accepted by the Japanese people. It was General MacArthur who guided the Japanese leaders toward this goal - Japan as the "Switzerland of Asia". However, fortunately or unfortunately, it did not take long before Japan had to give up such "non-arms" peace-state position because of an unexpected external force.

The second shock came to Japan when the Korean war broke out, and all the combatant forces were immediately sent to Korea from Japan. This "vacuum shock" caused the Japanese change, of course, towards forming up their own self-protection forces, initially in the name of "Police Reserve Force", then "National Security Force", and finally the present "Self Defense Forces". The Korean Peninsula has always been one of the important "threat routes" to the Japanese. The same kind of "vacuum shock" in the shape of the "Nixon Doctrine" after the Vietnam War debacle pushed Japan to increase the self-help efforts. As the American forces withdrew from the neighboring area, Japanese self-defence capability had to be promoted by the American request.

The third shock was with the MIG-25 incident. The defector Belenko landed surprisingly at the Hakodate airport, Hokkaido, the northern island of the Japan archipelago, penetrating through the blind part of the radar coverage, which was regarded as the same as "surprise attack" in war 
emergency. This could be said to be a "blind shock" or a "surprise attack shock" and Japanese authorities concerned felt the necessity of filling up the blind so that we could protect the sovereign territory from being destroyed without notice. This feeling as well as necessity was fortified when, surprisingly, the Russian troops invaded Afganistan.

The fourth shock is the "partnership shock". In spite of the closer relationship between the United States and Japan, increasing pressure have been brought to bear on Japan resulting in unpleasant feelings. What the United States have requested is that Japan should take a much greater "burden" and "cost" as a "partner" of the United States, visibly or invisibly. The breaking of the one percent of GNP barrier for the defence budget was forcibly realized by this shock. The "Toshiba incident" can be described as one of the "partner shocks". Even the "Ron-Yasu friendship" could not avoid a series of these shocks.

What shape would the next "fifth shock" take, then? If Japan were forced to invest more in the military in order to have a satisfactory capability in the eyes of the United States and other allies, this could be the one. However, my fear is that such shock would push Japan toward the same kind of situation we faced before the opening of the Pacific War as well as at the end of the war - frustrated responses. No one can tell at this moment whether another future shock would be paradoxically "Japan shock", which would surely break the common understandings broadly held as the Japanese postwar general attitudes. Anyway, this kind of "future shock" would not be pleasant to anyone in the world. I pray that it would never happen.

\section{Mathematical Magic of Japanese Defence Budget Figures}

According to the Report on Allied Contribution to Common Defence published yearly by the US Department of Defence, Japan "ranks last, or nearest to last, on all of the ratio measures surveyed, and thus quite clearly appears to be contributing far less than its share of what it is capable of contributing". But, theoretically speaking, it is not meaningful to evaluate defence efforts in terms of money. If, even now, Japan's state budget is calculated in a little different way or formulation, the defense budget is slightly changed. It is said, this alone could produce at least $1.5 \%$ of GNP. Some say it would even reach $2 \%$. If it is $1.5 \%$, Japan's defence expenditure will be the 6 th highest in the West. If it is $2 \%$, the expenditure will rise to the 4 th highest ahead of UK and 
France; there will be only the US, PRC and West Germany above Japan.

Let me give another interesting example of the magic of figures. It is the exchange rate of yen to dollar. Its up-and-down fluctuation will result in changes in the international ranking of Japan's defence expenditure. In an extreme case, let us suppose Japan's defence expenditures rises to $2 \%$ of GNP, or twice the current level, while the exchange rate settles at 150 yen to the US dollar. To our surprise, non-nuclear Japan's defence expenditures will instantly jump up ranking only after the US and USSR. Assuming the case of an exchange rate of 100 yen to US dollar and defence expenditures of $1 \%$ of GNP, the same level as at present, Japan also stands at the third, without even a penny increase, to our great surprise. Thus, a little change in the figures could well turn Japan into one of the leading military powers in the world.

Japanese contribution to security, which cannot be converted into monetary terms, is great, indeed, beyond expression. First, the topographical and strategic importance of Japan must be mentioned. The presence of Japan in the Far East as a member state of the Western alliance, itself constitutes a contribution of enormous significance. What would happen, if Japan stood for the East? The mere thought of it would cause a nightmare in the West. Secondly, the topographical importance of a Japan surrounded by sea is enormous. Even at the age of nuclear missiles no one can deny that such topographical merit of Japan provides a great contribution to the security of the West.

The third is Japan's offering of bases in Japan. Japan has undertaken the large expenditures concerning the US Forces stationed in Japan, to a degree which compars favorably with any NATO member state by now, and it is without doubt that Japan is contributing a great deal by offering bases with the highest capability and conditions in this strategically important area. This can never be converted to money. Japan is offering not only visible contributions such as land and services, but also invisible contributions such as technologies and talent.

The fourth is the economic aid Japan gives to the third world. It should be acknowledged how much it is contributing to the stabilization of conflictprone areas.

To summarize, we should understand well that it does not make sense to attempt international comparision of Japan's defence efforts merely by citing figures. It is necessary for both laymen and specialists to pay more attention to the defence efforts on the soft side, rather than stressing the hard sides. 


\section{Basic Principles of the Present Japanese Defence Policy}

The present Japanese national security policy is based on the principle of "Comprehensive National Security", which puts its foundation on the principles of (a) non-nuclear, (b) denial of militarism, having only "self-defence" capability, and (c) the US-Japan mutual security system. And, the triad of managing the comprehensive national security policy is (i) smooth and effective management of the US-Japan mutual security system, (ii) buildingup of the steady, moderate, efficient, and minimally-required capability for defending Japan, and (iii) pursuit of active diplomacy to stabilize the international environment.

The firm commitment to the US-Japan Mutual Security Treaty, the agreement of guideline for the mutual defence cooperation, operation of the joint exercises, conclusion of the military technology transfer to the US, various steps to reduce the financial burden of the US in having forces stationed in Japan, etc., entail: first, confirmation of the self-defence posture under the peace constitution, a negative position of refusing to become a military great power under tight civilian control, maintenance of the three non-nuclear principles; secondly, the decision of mid-term defence build-up program, the slight breaking of $1 \%$ GNP ceiling in defence expenditures, etc.; and, thirdly, efforts to maintain freedom and peace in cooperation with the West, continuing support for the dialogue towards peace and disarmament, efforts to stabilize various conflicts, including the Iran-Iraq war, the Cambodia problem and the North-South confrontation in the Korean Peninsula, economic assistance for stabilizing and developing the Third World, as well as economic cooperation to strengthen the political, economic and social foundation of less-developed states in an effort to contribute greatly to world peace and stability.

The present Japanese defence posture greatly differs from that of ten years ago. Let me remind you of one interesting story. Japanese authorities treated the Russian pilot who in 1976 defected in a MIG-25 as a violator against air traffic and immigration laws, not as an invader of Japanese territory. This was the reality of Japan's defence at that time. On the other hand, the latest debate, as you may have observed, has been very tolerant of the official attitude towards defence. Formerly, it was a taboo to talk about the subject, but now it is an open topic of debate; frankly I would say, because of pressure brought to bear on Japan, especially by the United States, and because of other 
external factors. The Japanese defence posture has changed remarkably.

\section{The Changing Nature of International Conflicts and Free-Thought Crisis Scenarios}

According to an article by Dr. Bertram, former Director of the London Institute of International Affairs, conflict in the 1980s is shaped by the following factors: First, military power cannot always play a decisive role in conflict resolution; second, the cost accompanying the use of military power has skyrocketed beyond any level in our previous experience; third, and consequently, the large scale application of modern military power is practically impossible - to be forced into such an application may mean the bankruptcy of the state. In other words, the political gains the state make by using military power is out of all proportion to the cost. The use of force is not only enormously expensive, but carries with it fatal risks at every political, economic, diplomatic and psychological level. Military costs cannot be balanced with the political benefits obtained.

Other professional papers presented at the various strategic meetings have listed the following additional factors to account for the changing nature of conflict. First, the ideological confrontation which laid the foundations of East-West conflict has faded away. Second, geographical distance matters less in the likely areas of conflict, given the rapid and remarkable development of means of communication and transportation; conflict becomes more likely in remote areas as well in neighboring areas. Third, territorial ambitions now count for less as sources of conflict than economic issues and issues involving natural resources. Fourth, most conflicts between nations are triggered by internal instabilities rather than external tensions. And fifth, "machismo" plays a role in theories of recent conflicts, among them confrontations between the United States and the Soviet Union, the Falkland conflict, the Iran-Iraq war, and others. This is a new interesting factor, especially cited by American strategic specialists.

Finally, to add one more special feature which determines international conflicts in the future. It is that confrontations within the Western or Eastern bloc are likely to take place more frequently than East-West confrontations. If I took a free-thought approach to the future Japanese defence problems along the line mentioned above the US-Japan decoupling scenario would be 
a more serious case than a Soviet invasion of Japanese territory. The second case would result from the first.The Japanese self-defence forces would then be defunctional caused by the cut of the US supply to Japan. The third crisis would also be between the US and Japan, in the form of a "Star Wars" between the two. In this way, future crisis scenario for Japan is likely to be "paradoxical".

\section{Range of Defence Choices for Japan and Three Actors}

In the changing nature of conflict Japan's defence options have to meet the following requirements: first, it should be able to respond to new challenges, and to further reflect the will of the people; secondly, it should be based on basic principles within the comprehensive conceptual framework of national defence; thirdly, it should be of a size proportionate to the national economy; fourth, it should have an adjustment function as well as a violence of destruction function; and fifth, if should be flexible enough to respond promptly to any unpredicted future critical situation. The importance of these requirements is to acknowledge the role of the military, not only in the application of force, but in the political arrangement and adjustment as well.

What about Japan's defence choices, given the changing nature of conflict and changing function of military power? Japan has a wide range of options in determining her defence policy, but aside from two extremes of full nuclear armament and total rejection of defence efforts, there are three main options currently receiving attention. The first is to continue the present policy, holding the defence budget at the level of about $1 \%$ of GNP. This would mean that quantity would be maintained or slightly increased while quality would be gradually upgraded in keeping with modern technology. A second option is the doubling of the size of current forces as rapidly as possible, together with a far-reaching upgrading of technological quality. This would see an increase of defence expenditures to a minimum of $2 \%$ of GNP and rise to $4 \%$ of GNP currently the level in the Federal Republic of Germany. The third option is a compromise between the other two, involving the gradual increase of both size and quality, with the likelihood of achieving a defence budget of $1.5 \%$ of GNP over a ten year period.

Which policy to be followed depends on many factors, not the least the assessment of the immediacy of the Soviet "threat". It is my belief that there is not yet in Japan a consensus between the policy decision level and the 
popular level of consciousness. In the determination of Japan's defence policy at least three elements or actors play major parts: first, political leadership; secondly, the bearer of the defence operation, the Self-Defence Forces; and thirdly, the popular base of support. It is not possible to bring about a strengthening of Japan's defensive forces unless all three elements take the same direction. Furthermore, there are two additional major elements. These are the intentions of the United States and the support and attitudes of the other governments of the Asia/Pacific region. These are matters which cannot, and should not be decided by Japan alone, even in the determination of Japan's defence. If Japan begins to adopt a policy of FukokuKyohei (enrich the country and strengthen the military), would American or Asian people approve? I believe that Japan was not wrong when she choose to become an Economic Power rather than a Military Power after 1945.

\section{Conclusion}

In concluding this paper, let me propose a new "Pacific Conflict Monitor and Prevention System" in which Japan can make a great contribution to meet the changing world's demand. This is a sort of modified version of the "Pacific Basin Cooperation" concept adopted by the late Prime Minister Ohira which put an emphasis on the Japanese role in the field of economic development of the region. My proposed model expanding the Ohira model more towards the "crisis control" or "country risk" measuring and management functions can offer a broader base of multi-national cooperation between the advanced and the less advanced states, in which each state may contribute its own "indigenous due" for the international integrated cooperation and inter-dependency to its utmost. Japan's role in this system is to be mainly non-military, but the Self-Defence Forces can take "peacekeeping" missions in the form of non-military functions, exploiting their technological professionalism. "Non-military use of military power" combined with "high-technology", would, I believe, be effective at various aspects in this new regional system, if the "political will" of each nation in this region did exist. 
Institute for Defense Studies, Tokyo, when this lecture was delivered. Since November 1987 he is Professor of International Political Science, School of Humanities and Social Sciences, Iwate (National) University, Marioka, and continues to be active as a defense/foreign affairs commentator. 